\title{
The Importance of Location Factors in Determining Land Prices: The Evidence from Bratislava's Hinterland
}

\author{
Martin Mariš ${ }^{1}$ \\ ${ }^{1}$ Slovak University of Agriculture, Nitra, Slovakia \\ Received: 11 August 2020/Accepted: 4 April 2021
}

\begin{abstract}
Bratislava, the capital city of Slovakia, is currently experiencing a period of intensive suburbanisation, which in turn creates demand pressures and increases the price of urban land located in its hinterland. This paper investigates several locational factors, which likely significantly influence the demand for land plots and modulate 'pricemaker' conditions. Based on the population sample of 102 units, the results indicate that built-in infrastructure facilities on land under analysis, advanced transport connectivity in municipalities, and various amenities in the municipality cadastre tend to elevate land prices significantly. Moreover, the factor of distance from the city of Bratislava plays a major role in household location, which was identified by the apparent decreasing rent gradient pattern.
\end{abstract}

JEL classification: R11, R14, R31

Key words: land economics, rent gradient, suburbanization, bid-rent function

\section{Introduction}

In the last decades, Slovakia's core settlements are facing an ongoing process of suburbanisation, which establishes a network of small municipalities interconnected by a population of commuters. Rising demand for land and competition among dwellers compels municipalities to access new construction areas, which in turn places upward pressure on land prices.

The study's objective is to examine the dynamics of building land prices across various suburbs of Bratislava, the capital of Slovakia. According to preliminary data, building land prices in the Bratislava region far exceed prices for building land located in the rest of Slovakia. We propose that the main cause is the spatial proximity of Bratislava, to which all municipalities located in its catchment area are strongly connected.

As a basic reference model, we will utilise Alonso's Model (1964), considering a monocentric city with a central business district (CBD) to which all economic activities are connected. We will make a slight modification of the original model by focusing only on those land plots located in suburban zones and transitive-rural areas located behind Bratislava. Using empirical data on vacant land plots assigned for construction, we estimate the land plots' rent gradient at various distances from the Bratislava city. Considering distance and other variables assists us to assemble several distinct models 
expressing the location factors that are likely driving bidding market prices for land plots in municipalities around Bratislava city.

Although location theories are generally well explored (Blažek, Uhlír 2011), land economics is not sufficiently explored in Slovakian conditions. There are a number of studies devoted to suburbanisation processes in the Bratislava hinterlands, but mostly their topics of concern are subsequent demographic and urban morphological changes (Bezák 2006, Faltan 2019, Faltan, Pašiak 2004, Novotný, Pregi 2017, Podolák, Šveda 2014, Šveda 2016, Šveda et al. 2016, Šveda, Pazúr 2018).

The city of Bratislava holds a significantly more prominent political and economic position relative to the rest of Slovakia. Regional disparities measured as a difference in real GDP per capita between the wealthiest and poorest regions are immense. In 2017 the Bratislava region recorded $€ 53,778$ /capita; however, the Presov region was at just $€ 13,861 /$ capita, more than $75 \%$ lower. Furthermore, the Bratislava region is the only Slovakian region that exceeds the EU average. The region's relative macroeconomic performance reached $180 \%$ of the EU average in 2017. There are similar regional differences in other variables like labour productivity or household incomes. Concerning other real assets, the median of total real assets ranges from $€ 44,300$ in the Banska Bystrica region to $€ 92,200$ in Bratislava and reaches $€ 61,800$ per average household at the national level (National Bank of Slovakia 2019, Messner, Zavadil 2014).

The aforementioned differences are also reflected in housing prices or building land prices. According to 2020 National Bank of Slovakia (NBS) data, in absolute values, the average price of apartments in $€ / \mathrm{m}^{2}$ of floor area is highest in the Bratislava region $\left(€ 2,360 / \mathrm{m}^{2}\right)$ and lowest in the Nitra region $\left(€ 988 / \mathrm{m}^{2}\right)$, while the national average is $€ 1,792 / \mathrm{m}^{2}$. However, house prices are considerably lower, with the national average at $€ 1,336 / \mathrm{m}^{2}$. Building land prices are highest in the Bratislava region $\left(€ 158.63 / \mathrm{m}^{2}\right)$ and lowest in the Nitra region ( $\left.€ 33.76 / \mathrm{m}^{2}\right)$, with the national average at $€ 74.82 / \mathrm{m}^{2}$ and a considerable standard deviation of 107.58 (National Bank of Slovakia 2020, Dluhoš 2017).

\section{The Theoretical framework}

\subsection{Historical Approach to the Land and Location Economics}

The term rent is a common word for which economists assign a specialised meaning. In their day-to-day use of this term, most people think of the payments made to property owners to use their land and buildings; however, this term has evolved over centuries to denote slightly different things (Samuelson, Nordhaus 2005, Mankiw 2009). Samuelson, Nordhaus (2005) consider rent or net economic rent to be a price for land use or other production inputs, whose supply is fixed. Thus, rent is what is paid for the use of factors of production with a fixed supply. Mankiw (2009) distinguishes two different prices: the cost of acquisition and rent price. The cost of acquisition of land or capital is an amount that an agent pays for time indefinite possession of a factor of production. The rent price is an amount that is needed to pay for using the factor of production for a definite length of time. McConnell et al. (2009) highlight rent differences based on physical factors; the location of land itself may be just as important in explaining differences in rent. Other things equal, renters will pay more for a unit of land that is strategically located with respect to materials, transportation, labour, and customers than they will for a unit of land whose location is distant from these things.

The theory of land rent, being a rather complicated economic category, has an established methodological basis developed by representatives of the classical school of political economy. In that era, land rent had been seen through the lens of its products related to agricultural fertility (Ricardo 1817, Smith 1776, Mill 1848). Smith (1776) perceived rent as the price paid for land use, which is naturally the highest that the tenant can afford to pay considering the land's characteristics. The rent charged for land is frequently no more than what represents a reasonable profit or interest for the stock laid out by the landlord upon its improvement (Smith 1776). Ricardo (1817) refers to land rent in relation to compensation paid to the land owner for use of its original and indestructible powers (Ricardo 1817). 
Location theories are considered as predecessors to regional development theories. They stem from a neoclassical foundation, and their goal is to establish factors affecting the location of economic activities, and to explain the spatial distribution of economic activities (Blažek, Uhlír 2011). The importance of the location concept in early literature sources has been traditionally linked with distance. The oldest literature dedicated to understanding interrelationships between location and transport includes von Thünen (1826), Launhardt (1882, 1885), Weber (1929), Palander (1935), Lösch (1954), Dean (1938), Hoover (1937), Dunn (1954), Greenhut (1956), Isard (1956) and Lefeber (1958) who have contributed to the element of general location theory that also implicitly accounts for transport costs (Isard et al. 1998, Bertuglia et al. 2013).

Location models differ according to their hypotheses on the spatial structure of demand and supply, which reflect the aims that the models pursue. Some models aim to interpret firms' location choices on the assumption of punctiform final and raw materials markets with given locations. Other models seek to identify the market areas of firms, that is, the division of a spatial market among producers (Weber 1929, Greenhut 1956). Location equilibrium is determined by a logic of profit maximisation whereby each producer controls its market area (Lösch 1954, Hotelling 1929). Finally, location theory analyses the economic and spatial mechanisms that regulate the size of territorial agglomerations, functional specialisation, and territorial distribution (Christaller 1933, Lösch 1954). These models put forward a more complex and general theory of location and the structure of the underlying economic relations that account for the existence of diverse territorial agglomerations within a framework of general spatial equilibrium (Capello, Nijkamp 2009).

Ideas about economic relations between the space and structures were first pioneered by von Thünen (1826) through an example of agricultural use. He demonstrated how economic forces contribute to the evolution of regional differences in land use. Besides traditional factors like quality and soil fertility, the land's geographical position or location plays a substantial role in different use of the land (Maier, Tödling 1995). The location rent represents the maximum payment that farmers could afford to pay to the landowner. On a given condition, location rent represents potential profit, independent from institutional factors (Maier, Tödtling 1997). In other words, the land rent is residual, as it equals the difference between the cost resulting from the production and transportation of the product at the 'marginal site,' which is equal to the product's return, and the costs that have to be incurred at the place currently under consideration (Fischer 2011).

No two such gradients are identical. The level and the structure of transfer costs naturally influence the slope and rent gradients' shape. When the transfer is costly, the ceiling rent for any given kind of use drops off rapidly with increasing distance; but along a route of cheap transfer, the corresponding rent gradient is relatively flat. An accentuated concavity of the gradients characterises the latter; i.e., ceiling rents fall off rapidly with increasing distance from the market as long as the distance is short, but less and less rapidly as longer hauls are involved. Finally, the gradient slope will differ according to the amount and transferability of the product produced per unit of land, which is not the same as the intensity. The process that yields a large volume of output per unit of land, particularly if it is expensive to distribute, has relatively steep rent gradients. Conversely, for land uses producing small amounts of easily transferable products per unit of land, the rent gradient is flat (Hoover 1948).

The basic urban model focusing on the fundamental trade-off between accessibility and space in residential choice was developed by Alonso (1964), Mills (1967) and Muth (1969). Considering a monocentric city with a prespecified centre, called a central business district (CBD), where all jobs are located. In this context, the only spatial characteristic of a location is its distance to the CBD (Fujita, Thisse 2002). Alonso (1964) reinterpreted the Thünen model by using households' location within the urban area. The trade-off theory is based on the perception that each household is willing to spend some amount of money on housing as a fraction of its income in a given market condition. The optimal locality of the household is determined by expenditures, which depend on location decisions. A minimum of total costs represents the optimal locality as a sum of transport costs, which are rising outwardly from $\mathrm{CBD}$, and rental costs, which in turn are declining outwardly 
from CBD (Maier, Řezáč 1997, Maier, Tödtling 1997, Brakman et al. 2003). The role of transport costs and land value leads to a key concept in classical urban economics, the bid-rent curve (or bid-rent function). The bid-rent is the maximum rent that a potential user is willing to pay for a site or location. Each potential user of land has a bid-rent curve (or function), which relates the user's bid-rent to the location of the land site, showing in particular how the bid-rent changes as a function of the user's distance from some central point. The central point is the point at which the transportation costs are minimised for that use, the point at which the bid-rent or residual value is maximised (Geltner et al. 2014). The nature of diminishing rent gradients with rising distance from the CBD have been widely confirmed in a number of studies (Glumac et al. 2019, Colwell, Munneke 1997, Abelson 1997, Atack, Margo 1998). However, there were also some inconclusive (Heikkila et al. 1989), mixed, and also contradictory results (Shimizu, Nishimura 2007, Plaut, Plaut 2003).

\subsection{Value of location in the land price determination}

Real estate can be purchased or leased within any sub-national region at a great range of prices or rents. Price increases with the land's suitability for construction, the public services available to it (public water, drainage sewers, sanitary sewers, electric power, natural gas service, etc.), proximity to the transportation network of all modes, and proximity to transportation and employment nodes (urban and suburban commercial cores, superhighway interchanges) (Harrington, Warf 2002). Competition for land plays an important locational role in areas where activities tend to concentrate for any reason. Locations with good soil, climate, access to other areas, and areas suitable for agglomeration under local external economies' influence are in demand. The price of land, which is our best measure of the intensity of demand and competition for land, varies with quality and access, and rises abruptly to high peaks in urban areas (Hoover, Giarratani 2020). The primary determinant of the cost of land is its accessibility. Transport costs (the measure of accessibility) determine parcels' location rent at different distances from the city. Thus, because land downtown is the most accessible, it is the most expensive; in most cities, costs decline exponentially away from the city centre (Stutz, Warf 2012).

A complex set of factors impacts the choice of residential location. Extensive analysis of modelling the choice of residential location via a multinomial logit model is provided by McFadden (1978) and McFadden (1973), Quigley (1976), and Lerman (1975). McFadden (1978) asserts that an economically rational consumer will choose a residential locality by weighing the attributes of each available alternative - accessibility of workplace, shopping, and schools; quality of neighbourhood life, taxes, and travel costs; and dwelling characteristics, such as age, number of rooms type of appliances - and by choosing an alternative that maximises utility. Lerman (1975) describes the household location decision model using factors like locational attributes, transportation level of service to work, spatial opportunities, and the household's socioeconomic characteristics. Household choice among eighteen types of residential housing in a metropolitan area is shown to vary according to a household's income and size (Quigley 1976).

Three main theories are used to explain private-sector housing location: travel-cost minimisation, the travel-cost/ housing-cost trade-off, and maximum housing expenditure. Of the three theories, the second is the most widely accepted and, for this reason, has become the most developed theory of residential location. It essentially states that, given an opportunity, a perfectly mobile household would move to a plot where it can satisfy its spatial requirements while paying acceptable transport costs (Phe, Wakely 2000). Bayoh et al. (2006) show empirical evidence that rising incomes, lifecycle effects, residential filtering, transportation changes, and employment decentralisation are likely factors driving suburbanisation in which changes in these conditions make suburban locations more attractive to city residents. 
Schirmer et al. (2014) propose a four-tier classification of location variables:

- The built environment, defined by geometrics and volumes of spatial objects, including buildings, parcels, blocks, and connecting networks (both road and public transport networks).

- Socioeconomic environment, which describes various aspects of society: population size, income level, ethnic distribution, age, and education level. These variables are usually available at a certain aggregation level, such as neighbourhood, postal district, census block, or grid cell.

- Points of interest provide functions relevant to the public. For instance, the city centre within the CBD, or a hospital.

- Accessibility is the product of interest points and a transport network. As such, it contains a transport component and land-use component.

Kim et al. (2005) identified a trade-off process between transport and amenities, in that individuals prefer residential locations with a combination of shorter commuting time, lower transport costs, lower density, and higher quality of schools. Among other factors influencing the location of residential construction, Rietveld, Wagtedonk (2004) found the accessibility of workplaces, distance to railway stations, and, to a lesser extent, the accessibility of nature, surface water, and recreational areas. Similar conclusions were found by Naess (2006), Manivannan, Somasundaram (2014), and Yan (2020). Zrobek et al. (2015) based on a social survey, performed a more exhaustive search for the factors which likely influence residential location choice. Among the considered factors, price became the most important factor in the buyer's residential property choice. It was followed by 'quiet neighbourhood' and 'sense of security'. High scenic value, was regarded as a moderately important factor. The other natural features, such as the proximity of water bodies, air quality and undeveloped space, were regarded as not important.

When discussing land plot evaluation or real estate in general, we might speak about hedonic pricing models, which are widely used for this purpose (Saphores, Li 2012, Brander, Koetse 2011, Glumac et al. 2019, Mirkatouli et al. 2018). The analysis of hedonic markets in a perfectly competitive setting was pioneered by Rosen (1974). His hedonic model characterises markets for heterogeneous goods (or amenities) that implicitly price out attributes that characterise the goods (or factors or amenities) (Ekeland et al. 2004).

There are a number of techniques for estimating the hedonic pricing of real estate properties. Hannonen (2008) generally distinguishes three approaches to estimation: (1) parametrically, (2) semiparametrically, and (3) nonparametrically. Parametric modelling represents the classical approach in hedonic modelling, which is theory-laden because pre-specified functional forms are used in the analysis. Nonparametric techniques are on the other hand, data-driven, very flexible tools, and semiparametric techniques combine features from parametric and nonparametric approaches.

Among the parametric approaches, mainly ordinary least square regression (OLS), spatial autoregressive, and geographically weighted regression models were deployed to model hedonic real estate prices/rents, like Löchl, Axhausen (2010), Zrobek et al. (2014), Ahlfeldt (2008), Shimizu, Nishimura (2007), Farber, Yeates (2006). Nonparametric approaches include area-to-point Kriging and local regression estimation methods which mostly model effects of location on objects of study (for instance property prices) (Clapp 2003, McMillen 2001, Yoo, Kyriakidis 2009). Combes et al. (2018) developed a new methodology to estimate urban costs' elasticity using French data. In an extensive analysis, they investigated, among other topics, specific distance gradients for land prices in several French cities. Using the data panel approach by applying a non-linear econometric model, they provide estimates for land values in French urban areas. Among the results useful for our analysis, they found that the land price tends to rise with road access, basic utilities, and vacant land, and fall with rising distance. While distance gradients differ across urban areas they are in most cases negative. Land price gradients are in general much steeper than house price gradients. 


\subsection{Current Situation of the Housing Market in Bratislava's Hinterlands}

The rapid development of the housing market since the turn of the century is likely to be the primary cause of suburbanisation in Slovakia. The most important factors were the growth of GDP, real incomes, FDI inflow and government policy reforms on a national and local level (Špirková 2008, Golej et al. 2016, Drachal 2013).

Faltan (2019) argues that the first signs of modern suburbanisation in Slovakia are visible in an area of Bratislava city and its hinterland beginning in the 1980s. Its character, architectural or social, was significantly affected by the urbanisation process with a strong dependence on the city of Bratislava. A commonly visible pattern is the transformation of gardening colonies located on the city periphery on permanent habituated objects. This trend has reportedly shifted to city suburbs or the countryside and gradually to other Slovakian cities.

Most authors attribute internal migration as the leading cause of ongoing suburbanisation tendencies in Bratislava's hinterlands (Faltan, Pašiak 2004, Bezák 2006, Podolák, Šveda 2014, 2019). Falţan, Pašiak (2004) characterise urban development in Slovakia after 1990 as typical in the transformation of urban and rural settlements, in human potential, in the economic base, and in its internal structures and relations. Bezák (2006) distinguishes four types of internal migration, in Slovakia on the perceived axis of the urban-rural dichotomy. During the 1980s, emigration from the countryside to cities was a decisive part of migration flows, while after 1990 counter-urbanisation tendencies had prevailed. Migration between the cities and the countryside is also seen over this period. Podolák, Šveda (2019) show that municipalities in the hinterland of Bratislava city are most active in the country with regards to ongoing suburbanisation. Two components play a crucial role in this trend - natural birth rate and migration balance. While the natural birth rate has been, in general, very low, sometimes negative, a strongly positive migration balance has ensured a net increase.

Šveda et al. (2016) provided deeper insights into the structural elements of suburbanisation occurring in Bratislava's hinterlands. They identified seven suburban types of municipalities located in the hinterland of Bratislava city; (i) Type 1 - Large-scale development in the suburban ring, (ii) Type 2 - Intensive development in an agricultural landscape, (iii) Type 3 - Intensive development in vineyards, (iv) Type 4 - Development driven by Hungarian in-migration, (v) Type 5 - Development in a natural environment, (vi) Type 6 - Second-home development on the Danube riverside, (vii) Type 7 - Development in rural periphery. The main classification attributes were migration, dwelling construction, income, residential prices, and land use. According to the conclusions, better-educated and well-off social groups are the primary agents of suburbanisation. Furthermore, these people prefer localities in the city's vicinity, which leads to higher prices and rents of real estate in these municipalities. In turn, people with primary and secondary education are more likely to move to more distant residential areas.

Housing prices in the Slovak Republic have seen phenomenal growth since 2002, outpacing house price growth in most other OECD countries. However, house price growth has been quite divergent across the country. The highest levels of price growth have predominantly been seen in the West of the country, which outpaced the rest of the country by $21 \%$ since 2005 for Bratislava, $32 \%$ for Trenčín and $14 \%$ for Trnava (Hüfner 2009, Cár 2018). Housing prices in Slovakia are being determined by demand-side factors such as social-demographic (population features), social-economic (income), social-politics (national savings, access to loans, interest rates). Relevant supply side factors include: territorial and legal (housing support, the supply of building plots, local zoning policy, others), and economical-technical (financial capital, number of apartments and others) (Cár 2009).

There is the evidence that the value of constructed dwellings and built-up areas is highest in the immediate hinterland of Bratislava city and gradually decreases towards the periphery (Šveda, Pazúr 2018, Šveda 2011, 2014). A relevant factor is the 'urban-rural continuum', in which the effects of suburbanisation decreases with increasing distance from the city (Slavík et al. 2011, Novotný, Pregi 2017).

In most cases, the final bid prices for land plots are determined by the market - a result of supply and demand. However, there are some cases when the market fails to 
determine the 'true' intrinsic value of a land plot. In the Slovakian context, real estate (asset) values might be appraised through the following approaches (Ilavský et al. 2012).

- Market value

- Market value on the public market

- General value (applied in Slovakia)

Ordinance no.492/2004 Coll. (Secretary of Justice of the Slovak Republic 2004) on the property's general value adjusts methods for determining the value of tangible assets like land, buildings, and others. It authorises the appraiser to use three possible approaches:

1. Comparative approach

2. Income capitalisation approach

3. Location differentiation approach

\section{Data and Methodology}

For this paper, we use the classical approach, which should, at best and in the simplest form, model causal relations between land plot prices and a subset of location factors based on a population sample. We will not consider either spatial dependency or spatial heterogeneity among the population sample, although it would be corrected for autocorrelation if detected. For this purpose, we intend to use several multiple regression models. All proposed models are based on the cross-sectional data collected in the spring of 2020, from a database of several web portals of real estate agencies, aiming at mediating the acquisition and sale of real estate. The population sample represents vacant land plots designated for construction in nominal prices.

It should be noted that this price represents the anticipated price for the land plot and does not represent the final price as a result of the real transaction. The real price paid for the land is disclosed in the transaction agreement, which is not public. However, this shortcoming should be ignored, as asked prices still reflect the prevailing market situation. Every land price advertised by real estate agencies are the result of the due diligence process performed by an agency. However, every agency uses a slightly different approach when setting the real estate value. Nonetheless, it is assumed that the price still overwhelmingly captures an 'intrinsic' value of the real estate property.

Initially, we estimate the following cross-sectional regression model with ordinary least squares, taking into account several location factors. The general model can be specified as:

$$
y_{i}=\alpha_{1}+\alpha_{2} E N_{2 i}+\alpha_{3} T_{3 i}+\alpha_{4} A_{4 i}+\beta_{1} X_{1 i}+\beta_{2} X_{2 i}+u_{i}
$$

where $y_{i}$ is the price of the land plot in $\mathrm{m}^{2}, E N_{2 i}$ is a dummy variable expressing the influence of engineer networks (electricity, gas, water, sewer) present in the land plot, $T_{3 i}$ is a dummy variable expressing the location factor of transport connectivity present in the municipality cadastre (railway, highway connection, etc.); $A_{4 i}$ is a dummy variable expressing the presence of the amenity in the municipality. In this case, several types of amenities were considered; natural - forest, river or pond, historical - castle, or manor house, and specialised services - sport facilities, tourism facilities, etc. We have given each variable equal weighting. In the case of the dummy variable $E N$, which assesses the impact of engineer networks present on the land plot, the variable is 1 - if all networks are found on the land plot (sewer, electricity and gas) and 0 - if not. If at least one network on the plot is missing, the statistical unit was not considered in the sample.

Among the quantitative variables, $X_{1 i}$ is a 'development fee', which represents a construction tax per $\mathrm{m}^{2}$ of the built-up area claimed by the municipality, and $X_{2 i}$ is a municipality's distance from the CBD of Bratislava city in $\mathrm{km}$.

The total population sample consists of $n=102$ units. The explanatory variable $X_{1}$, 'development fee', was adopted by Act no. 447/2015 on local fees for the development Coll., in 2015 (Slovak Republic 2015), thereby introducing the instrument regulating developers' activity in settlements. The municipality sets the amount of the fee according 
to the law. The amount of the fee is calculated as a product of the fee rate in $€$ and the floor area of the house in $\mathrm{m}^{2}$. In the first model, we will estimate the parameters based on the population sample, taking the general model, including all dummy variables.

Next, we shift attention to measuring the impact of distance from the city of Bratislava, thereby CBD, on prices of land plots in various municipalities located in the Bratislava hinterland. Based on theoretical and empirical sources, we intend to modify the regression function as:

$$
y_{i}=\alpha_{i} e^{\beta_{2} X_{2 i}}
$$

Where $y_{i}$ is a price for the land plot and $X_{2 i}$ is the physical distance of land plot $i$ from Bratislava city in kilometres. The metric physical distances were collected separately per each land plot via the google maps application, measuring the physical (travel) distance from the Bratislava centre (pedestrian zone) to the land plot located in each municipality according to its unique zip code. Finally, we will incorporate an exclusive dummy variable model (ANOVA), distributing the population sample to the predefined bands based on rising distance from the CBD. The distance bands were set according the univariate clustering algorithm using the XLSTAT program, setting following distance bands behind the Bratislava's urban perimeter:

Band 1: $0-13,5 \mathrm{~km}$

Band 2: $13,51-22,8 \mathrm{~km}$

Band 3: $22,81-32,2 \mathrm{~km}$

Band 4: $>32,2 \mathrm{~km}$

The Model can be specified as:

$$
y_{i}=\beta_{0} D_{i 1}+\beta_{1} D_{i 2}+\beta_{2} D_{i 3}+\beta_{3} D_{i 4}+u_{i}
$$

\section{Results}

Figure 1 shows a map of the Bratislava region and an overview of the study using the geographic information system (GIS) ArcMap 10.5.1. The red dot marks Bratislava city. There are municipalities located in several concentric rings around Bratislava city representing chosen distance bands. The fourth distance band is not represented by a ring. The shape of the rings is intentional, as it embodies superior statistical properties (Wong, Lee 2005). Land plots located in municipalities within and outside of the rings are the object of this research. They were picked at random based on the underlying data.

Table 1 shows the estimation results according to Model 1. The control variables are shown in $€ / \mathrm{m}^{2}$, as specified in Model 1 .

According to the model, all control variables have shown a statistically significant effect on the dependent variable (the price of the land per $\mathrm{m}^{2}$ ) except the Development fee. Interestingly, according to the model, with rising unit distance, land price per $\mathrm{m}^{2}$ declines by $€ 0.433 / \mathrm{m}^{2}$ on average, the presence of engineer networks on the land increases the price by $€ 0.208 / \mathrm{m}^{2}$, the presence of transportation facilities within the municipality cadastre increases the price by $€ 0.117 / \mathrm{m}^{2}$ and the presence of amenities in the municipality increases the price by $€ 0.249 / \mathrm{m}^{2}$.

In general, the model could be considered adequate. The coefficient of determination $\mathrm{R}^{2}$ shows an above-average value, and parameter $\mathrm{F}$ became highly significant. Possible spatial autocorrelation, measured by the Durbin-Watson statistic, shows only scant effect, and heteroscedasticity of the sample, according to the Breusch-Pagan test, is not detected. Therefore, according to the test presented in Table A.1, there is no issues of multicollinearity in the model (See Table A.1 of the Appendix).

Table 2 shows results of the effect of distance on the price of land plots. Considering the nonlinear relation between the dependent and independent variable and comparing various functional forms, the exponential regression model yielded most desirable qualitative features. 
Figure 1: The Bratislava region

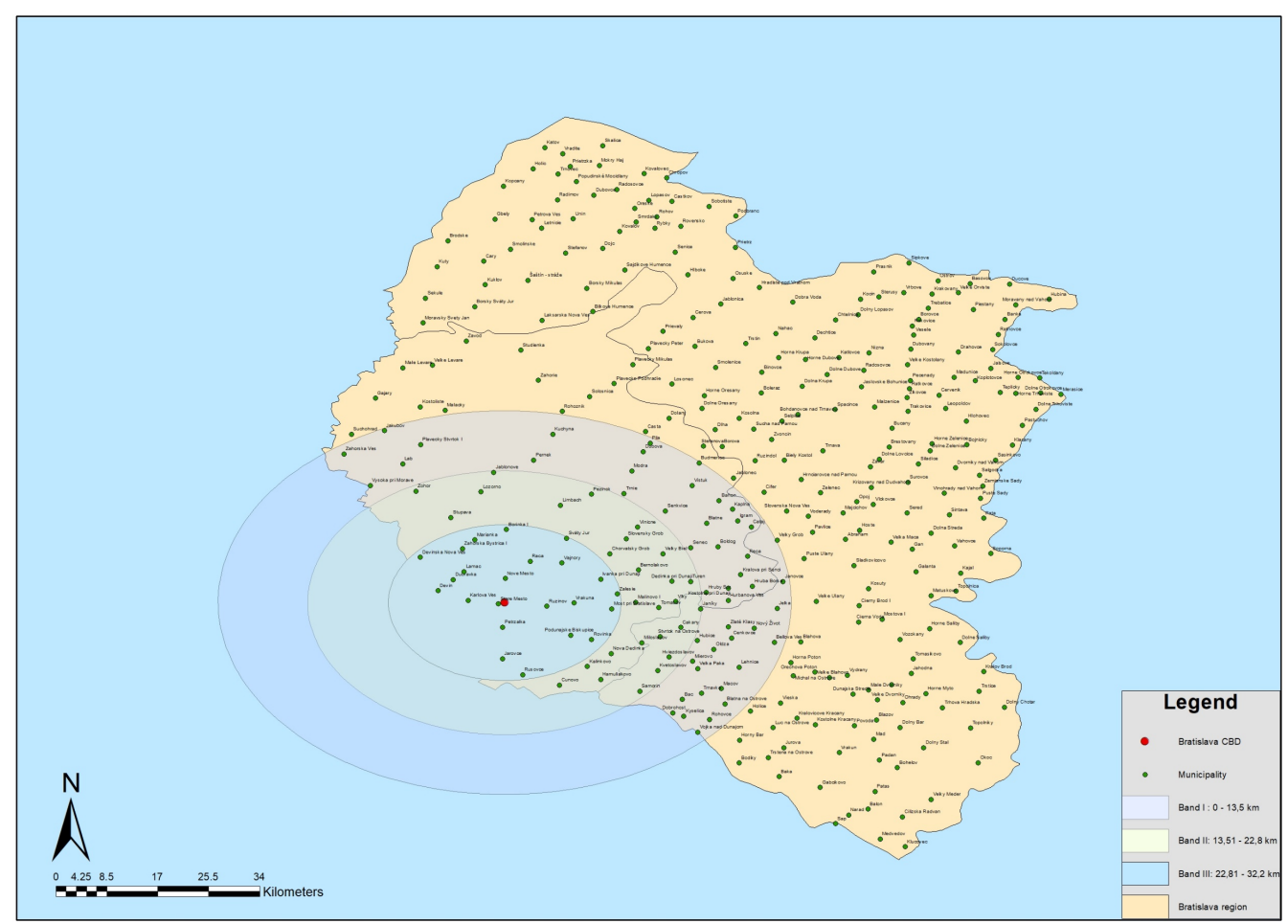

Table 1: General estimation results (Model 1)

\begin{tabular}{|c|c|c|c|c|c|c|}
\hline Source & Value & $\begin{array}{l}\text { Standard } \\
\text { error }\end{array}$ & $\mathrm{t}$ & $\operatorname{Pr}>|t|$ & $\begin{array}{l}\text { Lower } \\
\text { bound } \\
(95 \%)\end{array}$ & $\begin{array}{c}\text { Upper } \\
\text { bound } \\
(95 \%)\end{array}$ \\
\hline Intercept & 5.751 & 0.280 & 20.549 & $<0.0001$ & 5.195 & 6.306 \\
\hline Development fee & 0.032 & 0.034 & 0.936 & 0.352 & -0.036 & 0.100 \\
\hline Distance & -0.433 & 0.067 & -6.490 & $<0.0001$ & -0.565 & -0.300 \\
\hline E. networks & 0.208 & 0.057 & 3.657 & 0.000 & 0.095 & 0.321 \\
\hline Transportation & 0.117 & 0.057 & 2.061 & 0.042 & 0.004 & 0.230 \\
\hline Amenity & 0.249 & 0.060 & 4.119 & $<0.0001$ & 0.129 & 0.369 \\
\hline $\mathrm{R}^{2}$ & 0.580 & & & & & \\
\hline Adjusted $\mathrm{R}^{2}$ & 0.558 & & & & & \\
\hline DW & 1.773 & & & & & \\
\hline $\mathrm{F}$ & 26.463 & & & & & \\
\hline $\operatorname{Pr}>F$ & $<0.0001$ & & & & & \\
\hline
\end{tabular}

Table 2: General estimation results (Model 2)

\begin{tabular}{lrrrr}
\hline Source & Value & $\begin{array}{c}\text { Standard } \\
\text { error }\end{array}$ & $\begin{array}{r}\text { Lower } \\
\text { bound } \\
(95 \%)\end{array}$ & $\begin{array}{r}\text { Upper } \\
\text { bound } \\
(95 \%)\end{array}$ \\
\hline Intercept & 208.828 & 15.132 & 178.807 & 238.849 \\
Distance & -0.024 & 0.003 & -0.030 & -0.018 \\
\hline
\end{tabular}


Table 3: General estimation results (Model 3)

\begin{tabular}{crrrrrr}
\hline Source & Value & $\begin{array}{c}\text { Standard } \\
\text { error }\end{array}$ & $\mathrm{t}$ & $\operatorname{Pr}>|t|$ & $\begin{array}{r}\text { Lower } \\
\text { bound } \\
(95 \%)\end{array}$ & $\begin{array}{r}\text { Upper } \\
\text { bound } \\
(95 \%)\end{array}$ \\
\hline Dist. 1 & 182.736 & 10.822 & 16.885 & $<0.0001$ & 161.259 & 204.212 \\
Dist. 2 & -54.286 & 12.496 & -4.344 & $<0.0001$ & -79.085 & -29.487 \\
Dist. 3 & -85.827 & 12.339 & -6.956 & $<0.0001$ & -110.313 & -61.340 \\
Dist. 4 & -98.310 & 12.100 & -8.125 & $<0.0001$ & -122.321 & -74.298 \\
$\mathrm{R}^{2}$ & 0.452 & & & & & \\
\hline
\end{tabular}

According to Model 2, distance could be considered a critical factor in determining a suitable housing location, with a profound impact on the land plot price. The results imply that increasing the distance by one $\mathrm{km}$ from the $\mathrm{CBD}$ of Bratislava city may decrease the land plot price by $2.4 \%$ per $€ / \mathrm{m}^{2}$ on average. The model has good properties, and based on the test results, we can rule out possible autocorrelation or heteroscedasticity (Provided in appendix, Table A.2).

Finally, we assembled Model 3, estimating different land price gradients in various distances from the CBD. Distance boundaries were set using a univariate clustering algorithm, which seeks to maximise the classes' homogeneity due to minimising the sum of the within-class variance. The main comparing factor is Band 1. The left part of the table shows absolute differences in land prices in $€ / \mathrm{m}^{2}$ in among the distance bands.

Table 3 shows the variation in prices for land plots located in municipalities in different distance bands from Bratislava city. The model shows a decreasing rent gradient with increasing distance from the $\mathrm{CBD}$, which is in line with the theory. According to the proposed model, price in $€ / \mathrm{m}^{2}$ of the land plots located in the second distance band $(13,51-22,8 \mathrm{~km})$ is about $29,7 \%$ less compared to the first distance band $(0-13,5 \mathrm{~km})$; in the case of the third distance band $(22,81-32,2 \mathrm{~km})$; it is $54,2 \%$ less, and in the case of the fourth distance band $(>32,2 \mathrm{~km})$ it is $67,4 \%$ less than the price in the first band, on average. In the case of the fourth distance band, we considered the width of the band only up to $10 \mathrm{~km}$, as through empirical inspection we detected a sudden increase in land prices. A possible cause might be the spatial proximity of Trnava city, the capital city of the Trnava region on the NUTS 3 level. Centrifugal effects of Trnava city may be present which would therefore distort the sample.

All coefficients are highly significant and the model, in general, is adequate. Moreover, possible autocorrelation or heteroscedasticity was not detected (See Appendix, Table A.3).

Figure 2 shows a relation between the distance in $\mathrm{km}$ and price in $€ / \mathrm{m}^{2}$ for the land plot in the Bratislava region. The negative pattern of the scatterplot shows an apparent decrease in land prices when the distance increases.

\section{Conclusions}

The paper's primary objective was to examine the spatial variation of urban land prices in municipalities located in Bratislava's hinterland. The examination was primarily based on selected location factors, with a likely effect on land prices. Secondly, the factor of physical distance was assessed separately. Considering a monocentric city with a central business district (CBD) located in the centre, we used multiple regression as a primary method of research, combining quantitative and qualitative (dummy) search variables. The research results have shown a statistically significant impact of searched variables on urban land prices in various municipalities located in Bratislava's hinterland. Notably, the presence of alternative transport modes (railway or highway most notably) and built-in engineer networks on land plots have confirmed a sizeable impact on land prices. The presence of engineer networks on the land plot significantly elevates land prices. However, it was considered that land was fully equipped with all engineer networks (water, energy, sewer). 


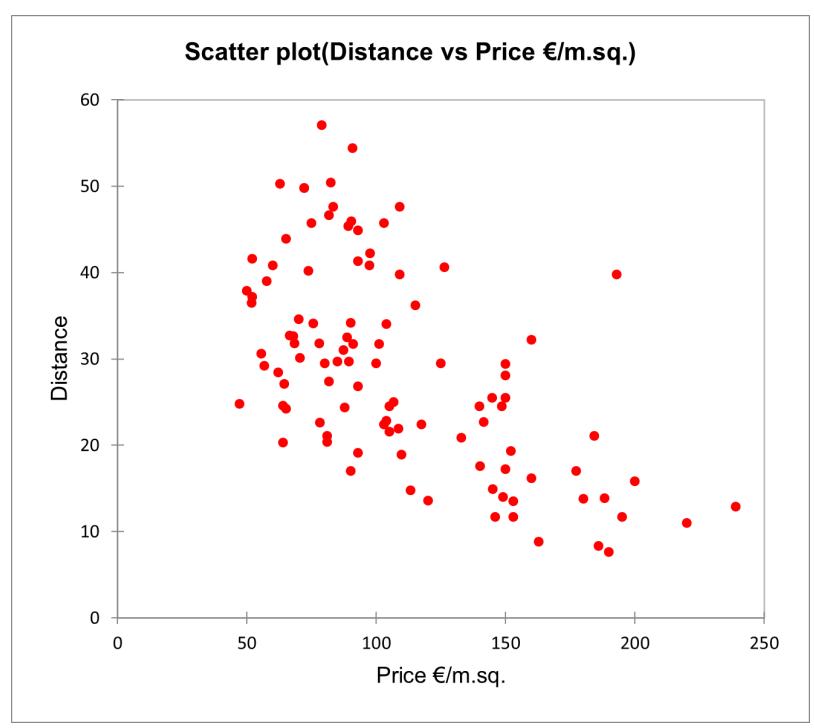

Figure 2: Scatterplot mapping distance vs price for land plots in Bratislava region

The effect of partially built networks is likely to be only minor. For the proprietor, built-in networks represent a significant reduction of costs, accelerating zoning and building procedures and thus making the land ready for building upon. Physical access to land plots also means important savings for the proprietor. Moreover, the spatial proximity of superior transport networks (like motorways or railways) to land likely represents a significant advantage for the proprietor when performing daily activities like commuting to work or for services in terms of time savings. The presence of local amenities nearby to land plots showed a significant price increase. With regards to higher aesthetic values, such localities give an impression of exclusivity for the proprietor and thus are in greater demand.

Similar conclusions were found by Ilavský et al. (2012), Harrington, Warf (2002), Rietveld, Wagtedonk (2004), Naess (2006) and Combes et al. (2018). Moreover, newly introduced land policy instruments aiming to regulate demand for new land plots have been shown to raise prices but so far fail to stem demand for the land plots. However, this factor hasn't become statistically significant. The reason might be that application of this is an exclusive competency of the municipality and thus the decision about fee rate is fully decentralised. It could be reasoned that municipalities are not perfectly informed about the fee rates in other municipalities, or that some municipalities hesitate to apply steep rates because they are afraid of stifling the influx of new citizens moving to the municipality.

The influence of physical access and distance to the land from Bratislava city is shown as statistically significant. For this purpose, we used the nonlinear method of regression in coherence with earlier theoretical knowledge and empirical findings (Stutz, Warf 2012, Zrobek et al. 2014, Hannonen 2008, Ahlfeldt 2008, Wang 2009). The results have confirmed a decreasing rent gradient with increasing distance from the CBD. Similar conclusions have been found by Glumac et al. (2019), Shimizu, Nishimura (2007), Combes et al. (2018).

This study is far from exhaustive; the analysis could therefore be extended to include other cities, varying by size and locations to reflect other geographical and social conditions. This study provides another piece of evidence showing that progressively rising rent gradients move inwardly to the city. The results also suggest that differences in price/rents of real assets mentioned by Cár (2018), Dluhoš (2017), Messner, Zavadil (2014), and National Bank of Slovakia (2020) between the Bratislava region and rest of Slovakia are primarily caused by the unique position of Bratislava city. 


\section{References}

Abelson P (1997) House and land prices in Sydney from 1931 to 1989. Urban Studies 34: 1381-1400. CrossRef.

Ahlfeldt GM (2008) If Alonso was right: Residual land price, accessibility and urban attraction. Munich personal RePEc archive. the Munich university library, Munich, Germany, https://mpra.ub.uni-muenchen.de/11707/. CrossRef.

Alonso W (1964) Location and Land Use. Harvard University Press, Cambridge, Mass. CrossRef.

Atack J, Margo AR (1998) 'Location, location, location!' The price gradient for vacant urban land: New York, 1835 to 1900. Journal of Real Estate Finance and Economics 16: 151-172. CrossRef.

Bayoh I, Irwin GE, Haab T (2006) Determinants of residential location choice: How important are local public goods in attracting homeowners to central city locations? Journal of Regional Science 46: 97-120. CrossRef.

Bertuglia CS, Leonardi G, Occelli S, Rabino GA, Tadei R, Wilson A (2013) Urban Systems: Contemporary approaches to modelling. Routledge (Original published 1987), London. CrossRef.

Bezák A (2006) Internal migration in Slovakia: Recent trends and spatial patterns. Geografický časopis/Geographical Journal 58: 15-44

Blažek J, Uhlír D (2011) Teorie Regionálního Rozvoje [Theories of Regional Development]. Karolinum

Brakman S, Garretsen H, van Marrewijk C (2003) An Introduction to Geographical Economics: Trade, Location and Growth (2nd ed.). Cambridge University Press, Cambridge. CrossRef.

Brander ML, Koetse JM (2011) The value of urban open space: Meta-analyses of contingent valuation and hedonic pricing results. Journal of Environmental Management 92: 27632773. CrossRef

Capello R, Nijkamp P (2009) Handbook of Regional Growth and Development Theories (1st ed.). Edward Elgar Publishing. CrossRef.

Christaller W (1933) Die zentralen Orte in Süddeutschland. Wissenschaftlische Buchgesellschaft, Darmstadt, Germany

Clapp MJ (2003) A semiparametric method for valuing residential locations: Application to automated valuation. Journal of Real Estate Finance and Economics 27: 303-320. https://papers.ssrn.com/sol3/papers.cfm?.abstract_id=287886

Colwell FP, Munneke JH (1997) The structure of urban economics. Journal of Urban Economics 41: 321-336. CrossRef.

Combes PP, Duranton G, Gobillon L (2018) The costs of agglomeration: House and land prices in French cities. Review of Economic Studies 86: 1556-1589. CrossRef.

Cár M (2009) Výber faktorov ovplyvňujúcich ceny nehnutelností na bývanie [the selection of real estate factors with impact on real estate prices]. Na aktuálnu tému 17: 2-8. http://www-ext.nbs.sk/_img/Documents/PUBLIK/MU/Car09-03-Biatec.pdf

Cár M (2018) Vývoj slovenského realitného trhu z regionálneho pohladu [the development of slovak real estate market from the regional perspective]. Makroekonomické otázky 26: 17-23. http://www.nbs.sk/_img/Documents/_PUBLIK_NBS_FSR/Biatec/Rok2018/02-2018/Biatec_18_2_05Car.pdf 
Dean HW (1938) The Theory of the geographic location of economic activities. Edwards Brothers, Inc

Dluhoš M (2017) An econometric model of real estate prices in Slovakia. European scientific conference of doctoral students, PEFnet, 44-54. https://pefnet.mendelu.cz/wcd/w-rek-pefnet/pefnet17_fin.pdf

Drachal K (2013) Analysis of the property market in Slovakia. Folia Pomeranae Universitatis Technologiae Stetinensis 73: 71-79

Dunn ES (1954) The Location of Agricultural Production. University of Florida, Gainesville FL

Ekeland I, Heckman JJ, Nesheim L (2004) Identification and estimation of hedonic models. Journal of Political Economy 112: 60-109. CrossRef.

Faltan (2019) Socio-priestorové premeny vidieckych sídiel na slovensku v začiatkoch 21. storočia - sociologická reflexia.[socio-spatial transformations of rural settlements in slovakia at the beginning of the 21st century - sociological reflexion]. Sociológia 51: 95-114. CrossRef.

Faltan, Pašiak J (2004) Regionálny rozvoj slovenska. východiská a súčasný stav [regional development of Slovakia. starting points and current situation]. SAV Bratislava

Farber S, Yeates M (2006) A comparison of localized regression models in a hedonic house price context. Canadian journal of Regional Science 29: 405-420. http://www.cjrsrcsr.org/archives/29-3/6-Farber-Yeates.pdf

Fischer K (2011) Central places: The theories of von Thünen, Christaller, and Lösch. In: Eiselt H, Marianov M (eds), Foundation of Location Analysis. Springer. CrossRef.

Fujita M, Thisse FJ (2002) Economics of Agglomeration: Cities, Industrial Location, and Regional Growth (1st ed.). Cambridge University Press, Cambridge. CrossRef.

Geltner MD, Miller NG, Clayton J, Eichholtz P (2014) Commercial Real Estate: Analysis and Investments (2nd ed.). OnCourse Learning, Mason, $\mathrm{OH}$

Glumac B, Herrera-Gomez M, Licheron J (2019) A hedonic urban land price index. Land Use Policy 81: 802-812. CrossRef.

Golej J, Pánik M, Špirková D (2016) Post-crisis development of residential real estate prices and their determinants of influence in Slovakia. 16th international multidisciplinary scientific geoconference SGEM 2016, 441-451. https://www.sgem.org/sgemlib/spip.php?.article7407

Greenhut M (1956) Plant Location in Theory and Practice. University of North Carolina Press, Raleigh NC

Hannonen M (2008) Predicting urban land prices: A comparison of four approaches. International Journal of Strategic Property Management 12: 217-236. CrossRef.

Harrington WJ, Warf B (2002) Industrial Location: Principles, practice and policy. Routledge. (Original work published 1995), London. CrossRef.

Heikkila E, Gordon P, Kim IJ, Peiser BR, Richardson WH, Johnson DD (1989) What happened to the CBD-distance gradient? Land values in a policentric city. Environment and Planning A 21: 221-232. CrossRef.

Hüfner F (2009) Adjusting housing policies in Slovakia in light of Euro adoption. Report no. ECO/WKP (2009)23. OECD. CrossRef.

Hoover ME (1937) Location Theory and the Shoe and Leather Industries. Harvard University Press, Cambridge, MA. CrossRef. 
Hoover ME (1948) The Location of Economic Activity (1st ed.). McGraw-Hill, New York

Hoover ME, Giarratani F (2020) An Introduction to Regional Economics. Regional Research Institute, West Virginia University, Morgantown, WV. https://researchrepository.wvu.edu/cgi/viewcontent.cgi?article=1003\&context=rri-web-book

Hotelling H (1929) Stability in competition. Economic Journal 39: 41-57. CrossRef.

Ilavský M, Nič M, Majdúch D (2012) Ohodnocovanie nehnuteLností [Real Estate valuation]. MIpress, Bratislava

Isard W (1956) Location and Space-Economy: A general theory relating to industrial location, market areas, land use, trade, and urban structure. The Technology Press of Massachusetts Institute of Technology, Cambridge MA

Isard W, Azis IJ, Drennan MP, Miller RE, Saltzman S, Thorbecke E (1998) Methods of Interregional and Regional Analysis. MPG Books Ltd, Bodmin, UK. CrossRef.

Kim J, Preston J, Pagliara F (2005) The intention to move and residential location choice behaviour. Urban Studies 42: 1621-1636. CrossRef.

Launhardt CWF (1882) Die Bestimmung des zweckmässigsten Standortes einer gewerblichen Anlage. Zeitschrift des Vereines deutscher Ingenieure 26: 105

Launhardt CWF (1885) Matematische Begründung der Volkswirtschaftslehre. Verlag von Wilhelm Engelmann, Leipzig

Löchl M, Axhausen WK (2010) Modelling hedonic residential rents for land use and transport simulation while considering spatial effects. The Journal of Transport and Land Use 3: 39-63. CrossRef.

Lefeber L (1958) Allocation in space. North Holland Publishing House, Amsterdam

Lerman RS (1975) Location, housing, automobile ownership, and mode to work: A joint choice model. Transportation Research Record 610: 6-11. http://onlinepubs.trb.org/Onlinepubs/trr/1976/610/610-002.pdf

Lösch A (1954) The Economics of Location. Yale University Press, New Haven CT

Maier G, Tödling F (1995) Regionálna a urbanistická ekonomika: Teória lokalizácie a priestorová štruktúra /Regional and urban economics: Theory of localization and spatial structure] (translation: M. Buček (2nd rev. ed.). Springer Verlag (Original work published 1992), Vienna. CrossRef.

Maier G, Tödtling F (1997) Regionálna a urbanistická ekonomika 2: Regionálny rozvoj a regionálna politika [Regional and urban economics: Regional development and regional policy] (Buček, M., Translation (2nd rev. ed.). Springer Verlag Wien, Vienna. CrossRef.

Maier K, Řezáč V (1997) Ekonomika v území, urbanistická ekonomika a územní rozvoj [economics in the territory, urban economics and territorial development]. ČVUT Praha

Manivannan P, Somasundaram M (2014) Purchase of residential flats - Factors influencing the decision buyers in selected cities in Tamil Nadu. International Research Journal of Business and Management 7: 67-73

Mankiw GN (2009) Macroeconomics (7th ed.). Worth Publishers, New York

McConnell CR, Brun SL, Flynn SM (2009) Economics: Principles, Problems, and Policies (18th ed.). McGraw-Hill/Irwin, New York

McFadden D (1973) Conditional logit analysis of qualitative choice behaviour. In: Zarembka P (ed), Frontiers in Econometrics. Academic Press

McFadden D (1978) Modelling the choice of residential location. Transportation Research Record 673: 72-77. http://onlinepubs.trb.org/Onlinepubs/trr/1978/673/673-012.pdf 
McMillen PD (2001) Nonparametric employment subcentre identification. Journal of Urban Economics 50: 448-473. CrossRef.

Messner R, Zavadil T (2014) Regional differences in household wealth across slovakia. National bank of slovakia. http://www.nbs.sk/_img/Documents/PUBLIK/OP__ 12014_Zavadil_Regional_Differences_Household_Wealth.pdf

Mill SJ (1848) Principles of Political Economy. Routledge, London. CrossRef.

Mills ES (1967) An aggregative model of resource allocation in a metropolitan area. American Economic Review 57: 197-210

Mirkatouli J, Samadi R, Hosseini A (2018) Evaluating and analysis of socio- economic variables on land and housing prices in Mashad, Iran. Sustainable Cities and Society 41: 695-705. CrossRef.

Muth RF (1969) Cities and Housing. University of Chicago Press, Chicago IL

Naess P (2006) Urban Structure Matters: Residential location, car dependence and travel behaviour. Routledge

National Bank of Slovakia (2019) Analýza konvergencie slovenskej ekonomiky [the analysis of convergence of slovak economy]. Národná banka slovenska. https://www.nbs.sk/__ img/Documents/PUBLIK/OP_2_2019_Analyza_slovenskej_konvergencie.pdf

National Bank of Slovakia (2020) Ceny byvánia pokračovali v 1. Štvrtroku 2020 v dynamickom raste [housing prices continues in growth in the 1st quarter 2020 in dynamical growth]. https://www.nbs.sk/_img/Documents/_komentare/2020/1189__ rk_cen_20200505.pdf

Novotný L, Pregi L (2017) Selective migration of population subgroups by educational attainment in the urban region of bratislava. Geografický časopis / Geographical Journal 69: 21-39

Palander T (1935) Beitrage zur Standortstheorie. Almqvist \& Wiksells Boktryckeri, Uppsala

Phe HH, Wakely P (2000) Status, quality and other trade-off: Towards a new theory of urban residential location. Urban Studies 37: 7-35. CrossRef.

Špirková D (2008) Determinanty rozvoja bytového trhu na Slovensku po roku 2000 [Determinants of the housing market development in Slovakia after year 2000]. Nehnutelnosti a bývanie 3: 20-40

Plaut OP, Plaut ES (2003) The inversion of the land gradient in the inner city of Haifa, Israel. Journal of Real Estate Research 25: 557-576. CrossRef.

Podolák P, Šveda M (2014) Fenomén neúplnej evidencie migrácie v suburbánnej zóne (na príklade zázemia Bratislavy) [the phenomenon of incomplete migration records in a suburban zone: The case of Bratislava hinterland]. Geografický časopis/Geographia Slovaca 66: 115-132. http://www.akademickyrepozitar.sk/sk/repozitar/fenomenneuplnej-evidencie-migracie-v-suburbannej-zone-na-priklade-zazemia-bratislavy.pdf

Podolák P, Šveda M (2019) Suburbanizácia len pre bratislavčanov? komponenty populačného vývoja zázemia Bratislavy $\mathrm{v}$ kontexte suburbanizačných procesov [suburbanization only for Bratislava residents? Components of population development of the Bratislava hinterland in the context of suburbanization processes]. In: Šveda M, Šuška P (eds), Suburbanizácia: Ako sa mení zázemie Bratislavy? [Suburbanization: How is the hinterland of Bratislava changing?]. Geografický ústav SAV, Bratislava, 104-134

Quigley JM (1976) Housing demand in the short run: An analysis of polytomous choice. NBER. https://www.nber.org/system/files/chapters/c9079/c9079.pdf 
Ricardo D (1817) Principles of political economy and taxation. Technical report, Amherst, NY. CrossRef.

Rietveld P, Wagtedonk JA (2004) The location of new residential areas and the preservation of open space: Experiences in the Netherlands. Environment and Planning A 36: 20472063. CrossRef.

Rosen S (1974) Hedonic prices and implicit markets: Product differentiation in pure competition. The Journal of Political Economy 82: 34-55. CrossRef.

Samuelson AP, Nordhaus DW (2005) Ekonomie [Economics] (18th ed.). (translation by Gregor et al.). Centa, s.r.o. (Original work published 1948)

Saphores DJ, Li W (2012) Estimating the value of urban green areas: A hedonic pricing analysis of the single-family housing market in Los Angeles, CA. Landscape and Urban Planning 104: 373-387. CrossRef.

Schirmer MP, van Eggermond ABM, Axhausen WK (2014) The role of location in residential choice models. A review of literature. Journal of Transport and Land Use 7: 3-21. CrossRef.

Secretary of Justice of the Slovak Republic (2004) Ordinance no.492/2004 coll. on general value of the property. https://www.slov-lex.sk/pravne-predpisy/SK/ZZ/2004/492/20170901

Shimizu Ch, Nishimura GK (2007) Pricing structure in Tokyo metropolitan markets and its structural changes: Pre-bubble, bubble, and post-bubble periods. Journal of Real Estate Finance and Economics 35: 475-496. CrossRef.

Slavík V, Grác R, Klobučník M, Kohútová K (2011) Development of suburbanization of slovakia on the example of the bratislava region. Comenius university, http://www.humannageografia.sk/clanky/slavik_grac_klobucnik_kohutova_2011.pdf

Slovak Republic (2015) Act no. 447/2015 coll. on local fees for the development. https://www.slov-lex.sk/pravne-predpisy/SK/ZZ/2015/447/20191130

Smith A (1776) An Inquiry into the Nature and Causes of the Wealth of Nations. Shine Classics. https://www.ibiblio.org/ml/libri/s/SmithA_WealthNations_p.pdf

Stutz PF, Warf B (2012) The World Economy: Geography, Business, Development (6th ed.). Prentice Hall, Saddle River, NJ

Šveda M (2011) Suburbanizácia v zázemí bratislavy z hladiska analýzy zmien krajinnej pokrývky [suburbanization in the hinterland of bratislava in the view of analysis of land coverage change]. Geografický časopis/Geographical Journal 63: 155-173

Šveda M (2014) Bytová výstavba v zázemí velkých slovenských miest v kontexte suburbanizácie a regionálnych disparít [dwelling construction in the hinterland of big slovak cities in the context of suburbanisation and regional disparities]. Geographia Slovaca 28: 173-195

Šveda M (2016) Život v Bratislavskom suburbia: prípadová štúdia mesta Stupava [the life in Bratislava's suburbia: The case study of the city of Stupava]. Sociológia- Slovak Sociological Review 48: 139-171

Šveda M, Madajová M, Podolák P (2016) Behind the differentiation of suburban development in the hinterland of bratislava, slovakia. Sociologický časopis/Czech Sociological Review 52: 893-926

Šveda M, Pazúr R (2018) Priestorové formy rezidenčnej suburbanizácie v zázemí Bratislavy [Spatial forms of residential suburbanization in the hinterland of Bratislava]. Geografický časopis/Geographical Journal 70: 231-258. CrossRef.

von Thünen JH (1826) The Isolated State. Oxford University Press, New York. CrossRef. 
Wang R (2009) The structure of chinese urban land prices: Estimates from benchmark land price data. The Journal of Real Estate Finance and Economics 39: 24-38. CrossRef.

Weber A (1929) Alfred Weber's Theory of the Location of Industries. University of Chicago Press, Chicago, IL

Wong WSD, Lee J (2005) Statistical analysis of geographic information. Wiley

Yan X (2020) Evaluating household residential preferences for walkability and accessibility across three U.S. regions. Transportation Research Part D: Transport and Environment. CrossRef.

Yoo HE, Kyriakidis CP (2009) Area-to-point kriging in spatial hedonic pricing models. Journal of Geographic Systems 11: 381-406. CrossRef.

Zrobek S, Belej M, Kovac SM, Cellmer R (2014) Urban land value maps - A methodological approach. Geodetski Vestnik 58: 535-550. CrossRef.

Zrobek S, Trojanek M, Zrobek-Sokolnik A, Trojanek R (2015) The influence of environmental factors on property buyers' choice of residential location in Poland. Journal of International Studies 7: 163-173. CrossRef. 


\section{A Appendix:}

Table A.1: Heteroscedasticity and multicollinearity tests of Model 1 results

\begin{tabular}{lrlrr}
\hline Breusch-Pagan test: & & Multicollinearity statistics: & \\
& & & Tolerance & VIF \\
\hline LM (Observed value) & 2.372 & Development fee & 0.802 & 1.247 \\
LM (Critical value) & 11.070 & Distance & 0.713 & 1.402 \\
DF & 5 & E. networks & 0.928 & 1.078 \\
p-value (Two-tailed) & 0.796 & Transportation & 0.802 & 1.246 \\
alpha & 0.05 & Amenity & 0.932 & 1.073 \\
\hline
\end{tabular}

Table A.2: Heteroscedasticity and autocorrelation tests of Model 2 results

\begin{tabular}{lrll}
\hline White test: & & Durbin-Watson test: \\
\hline LM (Observed value) & 1.203 & DW & 1.806 \\
LM (Critical value) & 5.991 & rho & 0.093 \\
DF & 2 & p-value (one-tailed) & 0.277 \\
p-value (Two-tailed) & 0.548 & alpha & 0.050 \\
\hline
\end{tabular}

Table A.3: Heteroscedasticity test of Model 3 results

\begin{tabular}{lr}
\hline White test: \\
\hline LM (Observed value) \\
LM (Critical value) & 1.203 \\
DF & 5.991 \\
p-value (Two-tailed) & 2 \\
alpha & 0.548 \\
\end{tabular}

c) (i) (-) () 2021 by the authors. Licensee: REGION - The Journal of ERSA, European Regional Science Association, Louvain-la-Neuve, Belgium. This article is distributed under the terms and conditions of the Creative Commons Attribution, Non-Commercial (CC BY NC) license (http://creativecommons.org/licenses/by-nc/4.0/). 